\title{
Studies on butterfly diversity (Lepidoptera: Papilionoidea) from Punjab Agricultural University Campus, Ludhiana, Punjab, India
}

\author{
P. C. Pathania ${ }^{1 *}$, H. K. Mangat ${ }^{2}$ and A. K. Sidhu ${ }^{3}$ \\ 'Zoological Survey of India, M-Block, New Alipore, Kolkata - 700053, West Bengal, India; pathaniapc@yahoo.co.in \\ ²Department of Entomology, Punjab Agricultural University, Ludhiana - 141004, Punjab, India \\ ${ }^{3}$ High Altitude Regional Station, Zoological Survey of India, Saproon, Solan - 173 211, Himachal Pradesh, India
}

\begin{abstract}
Thirty-three species referable to twenty-four genera belonging to five families, namely, Hesperiidae (1), Lycaenidae (6), Nymphalidae (14), Papilionidae (3) and Pieridae (9) from different localities of University campus were collected and identified. The details on their synonymy, material examined, and host distribution along with plants are provided. The photographs of the adults are also given.
\end{abstract}

Keywords: Butterfly, Diversity, Lepidoptera, Papilionoidea

\section{Introduction}

Biological diversity is the base for upholding the ecosystems and the functional aspects of the species that provide goods and services for human well-being (Wilson, 1997). Insects are the most dominate group of invertebrates with distinct three body parts (head, thorax and abdomen), three pairs of legs, compound eyes and body covered with chitinous exoskeleton. Butterflies belong to order Lepidoptera and distributed globally wherever the flowering plants are found (Khan et al., 2004). Butterflies are taxonomically well studied group, which have received reasonable amount of attention through the world (Ghazoul, 2002). The total number of butterfly species in the world range from 7700 (Kirby, 1872) to 20,000 (Landing, 1984). India hosts 1501 species of butterfly (Gaonker, 1996) out of 19,238 species described globally (Heppner, 1998). They are very delicate, beautiful and attractive due to their colorful scaly wings, considered as the symbol of beauty and grace (Rafi et al., 2000). They are diurnal (active at daytime) in habitats and easily recognized by their beautiful colour, shape and stylish flight that give pleasure to everyone (Javed, 1978). Butterflies have always attracted the attention of naturalists, amateurs, environmentalists, biodiversity discoverers and conservationists (Rose and Walia, 2003). Butterflies are important pollinators for many varieties of plant because they fly over long distance, but at the same time, some of them are very serious pest of many crops and fruits. Caterpillars of most Pierid butterflies feed on various varieties of mustards (family Brassicaceae), legume and cabbage (Mal et al., 2013). The study of biological diversity encompasses both the intrinsic and anthropocentric values associated with it. The values of the biological elements are recognized in correspondence to the perceived importance by the human being, which is realized in terms of the ecosystem services (Daily, 1997). Biological diversity is the base for upholding the ecosystems and the functional aspects of the species that provide goods and services for human well-being. Monitoring of species diversity of a region enables estimation of the prospective functional roles of the species. Therefore, monitoring species diversity acts as an enormous source of information of Super families

\footnotetext{
* Author for correspondence
} 
Papilionoidea from Punjab Agricultural University, Ludhiana. Furthermore, this checklist will be helpful for researchers to identify the species of butterfly.

\section{Material and Methods}

Study area: The present study was undertaken at Punjab Agricultural University (PAU), Ludhiana, established in 1962 and is the nation's third-oldest agricultural university. Itlies at $30.90^{\circ} \mathrm{N}$ and $75.85^{\circ} \mathrm{E}$ of Punjab in north-west India with an average elevation of $244 \mathrm{mASL}$. The university covers an area of 1,510 acres $\left(6.1 \mathrm{~km}^{2}\right)$ on its main campus. The temperature ranges from $1^{\circ} \mathrm{C}$ (in December/ January) to $45-46^{\circ} \mathrm{C}$ (in June) with the average annual precipitation of $730 \mathrm{~mm}$.

Localities: For study purpose, campus was divided into seven localities according to general landscape attributes (Figure 1). These were

1. Open fields

2. Orchards

3. Herbal and botanical gardens

4. Plant nursery

5. CIPHET, The Central Institute of Post-Harvest Engineering and Technology

6. Residential area

7. GADVASU complex

\section{Methodology Used}

The adults of the butterflies were collected with the help of insect collection net (circumference $93 \mathrm{~cm}$, handle length $87 \mathrm{~cm}$ and bag depth $77 \mathrm{~cm}$ ) sweeping method while exploring different localities of the campus. The collected adult specimens were killed with the killing agent like ethyl acetate, charged in the killing bottle. After killing, the dead specimens were kept in the relaxing jar for making the specimens soft. They were pinned using different size entomological pins $(38 \mathrm{~mm} \times 40 \mathrm{~mm} ; 38 \mathrm{~mm} \times 55 \mathrm{~mm})$, and then stretching of dead specimens were done in the spreading board boxes $(40 \mathrm{~cm} \times 30 \mathrm{~cm} \times 10 \mathrm{~cm})$. The stretched specimens were tagged with the labels carrying information such as name of collector, locality, alititude, date of collection, and then placed in the well fumigated (with naphthalene balls) air tight wooden showcases placed in the movable racks for storage. For wings slide preparation, the method proposed by Common (1970) and advocated by Zimmerman (1978) has been followed. The taxonomic procedures involves an examination of various morphological characters such as head, labial palpus, legs, wing shape, wing maculation and wing venation. Except wing venation, the rest of the characters have been directly examined from the dried specimens. The photographs of the adults belonging to different species were taken with the help of digital camera.

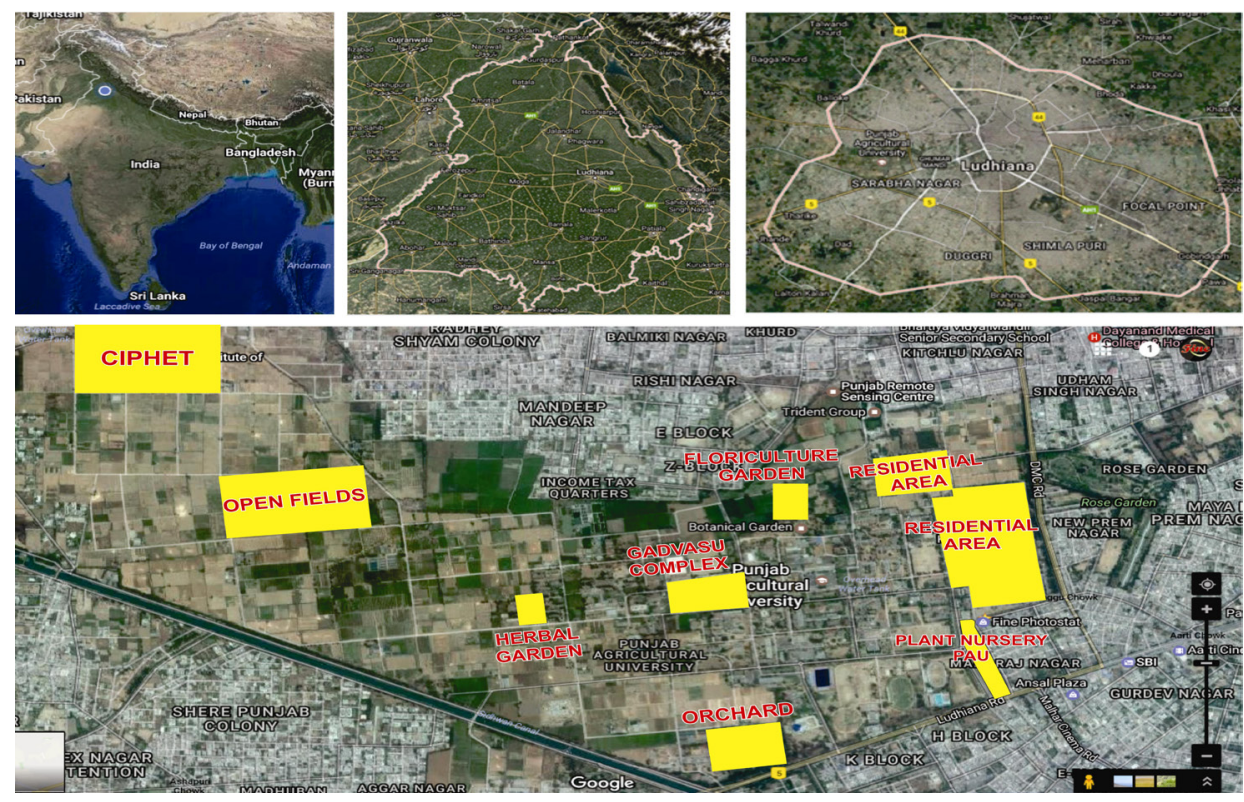

Figure 1. Study area. 


\section{Observations}

During different survery-cum-collection tours from the above said areas, the entire collection is sorted and identified. 33 species belonging to 24 genera of 10 subfamilies under 05 families of butterflies have been collected and identified. Genera such as genus Pelopidas Walker (Hesperiinae), Euchrysops Fabricius, Chilades Moore, Tarucus Moore, Catochrysops Boisduval, Talicada Moore (Polyommatinae), Rapala Moore (Lycaeninae), Phalanta Doubleday (Heliconiinae), Vanessa Fabricius, Hypolimnas Hübner, Junonia Hübner (Nymphalinae), Danaus Linnaeus, Euploea Fabricius, Tirumala Moore (Danainae), Melanitis Fabricius (Satyrinae), Papilio Linnae, Graphium Scopoli, (Papilioninae), Belonois Hubner, Cepora Billberg, Ixias Hübner, Pieris Schrank (Pierinae), Catopsilia Hübner, Colias Fabricius, Eurema Hübner (Coliadinae) are represented in the respective subfamilies. Status of abundance is shown as- VC: Very common, C: Common, LC: Less Common, R: Rare, VR: Very Rare (Table1 2, Photos 1-34, a-upperside, blowerside).

\section{Order LEPIDOPTERA}

Superfamily PAPILIONOIDEA

Family HESPERIIDAE

Subfamily HESPERIINAE

I. Genus Pelopidas Walker, 1870

1. Pelopidas mathias Fabricius (Photo $1 \mathrm{a}, \mathrm{b}$ )

Hesperia mathias Fabricius, 1798; Ent. Syst. (Suppl.): 433, no. 289-90; TL: Tranquebar, S.India

Material examined: (17ð̋ 9 9ㅇ). India: Punjab: PAU 5.xii.2012, Sunita, Kritika and Pathania (2ð 2 ○), PAU, 2.xi.2013, Kumar and Pathania (4ð3 3 ), PAU, 14.viii.2015, Sachin and Pathania (5 3 \% ), GADVASU, 17.viii.2015, Sachin and Pathania $(6 \hat{\jmath} 1$ ㅇ).

Distribution: India (Chandrasekharan, 2017)

Hostplant: Arecaceae and Poaceae (Kunte, 2000)

Family LYCAENIDAE

Subfamily POLYOMMATINAE

II. Genus Tarucus Moore

\section{Tarucus callinara Butler (Photo 2a, b)}

Tarucus callinara Butler, 1886, Ann.N.H. (5) 18: 185

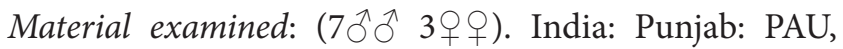
04.v.2009, Katewa, A. Seni and P.C. Pathania (4ð 2), PAU 18.viii.2012, Sunita, Kritika and Pathania (3ત1ㅇ).

Distribution: It ranges from North West Himalayas to Kumaun, the plains of northern India, central and Western India, Ceylon, Assam, Burma, Tenasserim (Bingham, 1907). Host plant: Plants of the legume family, Plumbaginaceae and some of the citrus family Rutaceae (Kunte, 2006).

\section{Genus: Euchrysops Butler}

3. Euchrysops cnejus Fabricius (Photo 3a, b)

Hesperia cnejus Fabricius, (1798), Ent. Syst. Suppl. 430.

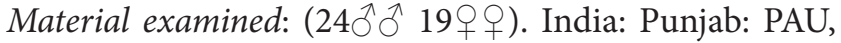
6.v.2009, Amit Katewa and P.C. Pathania (8 $\hat{\sigma}^{4}$ 우), PAU, 1.ix.2010, Vijay and P.C. Pathania (5ð 3 \% ), PAU, 20.xi,2012, Sunita, Kritika and P.C. Pathania $\left(6{ }^{\lambda} 1\right.$ 1 $)$, popen fields 30.xi,2012, Sunita, Kritika and P.C. Pathania (1今̂ 4우), PAU, 13.viii.2013, Avi Kumar and P.C. Pathania $\left(1 \delta^{\lambda} 2\right.$ ) $)$, PAU, 11.viii.2015, Sachin and P.C. Pathania $(1 \circlearrowleft$ ), GADVASU, 17.viii.2015, Sachin and P.C. Pathania

Table 1. Superfamilies, families, number of subfamilies, genera and species of butterflies recorded in PAU campus, Ludhiana (as per Van Nieukerken et al., 2011)

\begin{tabular}{|c|l|l|c|c|c|}
\hline SSr. No. & Superfamily & Families & No. of sub-families & No. of genera & No. of species \\
\hline \multirow{2}{*}{1} & \multirow{2}{*}{ Papilionoidea } & Pieridae & 2 & 7 & 9 \\
\cline { 3 - 6 } & & Papilionidae & 1 & 2 & 3 \\
\cline { 3 - 6 } & & Nymphalidae & 4 & 8 & 14 \\
\cline { 3 - 6 } & & Lycaenidae & 2 & 6 & 1 \\
\cline { 3 - 6 } & & Hesperiidae & 1 & $\mathbf{2 4}$ & $\mathbf{3 3}$ \\
\hline Total & $\mathbf{0 1}$ & $\mathbf{0 5}$ & $\mathbf{1 0}$ & & \\
\hline
\end{tabular}


Table 2. List of species with common names and along with their distribution

\begin{tabular}{|c|c|c|c|c|}
\hline Sr. no. & Family/ Subfamily & Scientific Name & Common name & Remarks \\
\hline \multicolumn{5}{|c|}{ Hesperiidae } \\
\hline 1 & Hesperiinae & Pelopidas mathias Fabricius & Small branded swift & Common \\
\hline \multicolumn{5}{|c|}{ Lycaenidae } \\
\hline 2 & Polyommatinae & Tarucus callinara Butler & The spotted pierrot & Rare \\
\hline 3 & Polyommatinae & Euchrysops cnejus Fabricus & The gram blue & Very common \\
\hline 4 & Polyommatinae & Chilades pandava Horsfield & The plains cupid & Common \\
\hline 5 & Polyommatinae & Catochrysops strabo Faricius & The forget-me-not & Common \\
\hline 6 & Polycnemoideae & Talicada nyseus Guerin Meneville & The red pierrot & Rare \\
\hline 7 & Lycaeninae & Rapala iarbus Fabricius & Common red flash & Very rare \\
\hline \multicolumn{5}{|c|}{ Nymphalidae } \\
\hline 8 & Heliconiinae & Phalanta phalantha Drury & Common leopard & Very common \\
\hline 9 & Nymphalinae & Vanessa cardui Linnaeus & Painted lady & Common \\
\hline 10 & Nymphalinae & Hypolimnas missipus Linnaeus & Danaid eggfly & Less common \\
\hline 11 & Nymphalinae & Hypolimnas bolina Linnaeus & The great egg-fly & Common \\
\hline 12 & Nymphalinae & Junonia almana Linnaeus & Peacock pansy & Less common \\
\hline 13 & Nymphalinae & Junonia atlites Linnaeus & Grey pansy & Very rare \\
\hline 14 & Nymphalinae & Junonia lemonias Linnaeus & Lemon pansy & Very rare \\
\hline 15 & Nymphalinae & Junonia orithya Linnaeus & Blue pansy & Common \\
\hline 16 & Nymphalinae & Junonia hierta Fabricius & The yellow pansy & Less common \\
\hline 17 & Danainae & Danaus chrysippus Linnaeus & The plain tiger & Very common \\
\hline 18 & Danainae & Danaus genutia Cramer & The common tiger & Very Common \\
\hline 19 & Danainae & Euploea core Cramer & Common crow & Rare \\
\hline 20 & Danainae & Tirumala limniace Cramer & - & Very rare \\
\hline 21 & Satyrinae & Melanitis leda Cramer & Common evening brown & Less common \\
\hline \multicolumn{5}{|c|}{ Papilionidae } \\
\hline 22 & Papilioninae & Papilio demoleus Linnaeus & Lime butterfly & Very common \\
\hline 23 & Papilioninae & Papilio polytes romulus Cramer & Indian common mormon & Very common \\
\hline 24 & Papilioninae & Graphium doson Felder & Common jay & Less common \\
\hline \multicolumn{5}{|c|}{ Pieridae } \\
\hline 25 & Pierinae & Belonois aurota Fabricius & The pioneer white & Less common \\
\hline 26 & Pierinae & Cepora nerissa Fabricius & Common gull & Less common \\
\hline 27 & Pierinae & Ixias mariane Cramer & White orange tip & Rare \\
\hline 28 & Pierinae & Ixias pyrene Linneaus & Yellow orange tip & Rare \\
\hline 29 & Pierinae & Pieris brassicae Linnaeus & Large Cabbage White & Very common \\
\hline 30 & Coliadinae & Catopsilia pomona Fabricius & Lemon emigrant & Less common \\
\hline 31 & Coliadinae & Catopsilia pyranthe Linnaeus & Mottled emigrant & Less common \\
\hline 32 & Coliadinae & Colias fieldii Ménétriés & The Dark clouded yellow & Less common \\
\hline 33 & Coliadinae & Eurema hecabe Linneaus & One-spot grass yellow & Common \\
\hline
\end{tabular}


(10 1우), Floriculture garden, 14.viii.2015, Sachin and P.C. Pathania (4ㅇ), CIPHET, 11.viii.2015, Sachin and P.C. Pathania $\left(1 \delta^{\Uparrow}\right)$.

Distribution: Species is spread throughout India except at very high elevations and is widely distributed in the Malayan subregion; extending to Australia and the South Sea Islands (Bingham, 1907).

Host plant: Fabaceae (Kunte, 2000).

IV. Genus: Chilades Moore

4. Chilades pandava Horsfield (Photo 4a, b)

Lycaena pandava Horsfield, [1829], Descr. Cat. lepid. Ins. (2): 84 (Lycaena).

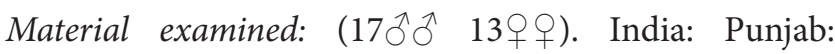
Orchard (PAU) 12.viii.2015, Sachin and P.C. Pathania (1ठ).

Distribution: It is found in Peninsular India south of the outer ranges of the Himalayas, Ceylon, Assam, Burma and extending into the Malayan Subregion (Talbot, 1939). Host plant: Cycadaceae, Fabaceae and Ulmaceae (Saji et al., 2017).

V. Genus: Catochrysops Boisduval

5. Catochrysops strabo Fabricius (Photo $5 \mathrm{a}, \mathrm{b}$ )

Hesperia strabo Fabricius (1793), Ent. Sys. 3.1:287 (Hesperia).

Material examined: (17ठํ 19우). India: Punjab: PAU, 12.v.2008, Katewa, A. Seni and P.C. Pathania (7ð 9ㅇ), PAU, 23.viii.2009, S. Chandel and P.C. Pathania $\left(2 \bigcirc^{\Uparrow} 4\right.$ 으,

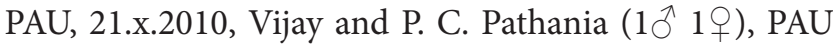
16.viii.2012, Sunita, Kritika and P.C. Pathania $(2 \hat{\jmath} 3$ + $)$, PAU, 8.ix.2013, Avi Kumar and P.C. Pathania (2犬̂), PAU, 4.vii.2015, Sachin and P.C. Pathania $\left(3{ }^{\wedge} 2\right.$ + $)$.

Distribution: Europe, Africa, South and Southeast Asia, and Australia (Bingham, 1907).

Host plant: Fabaceae (Kunte, 2000).

VI. Genus: Talicada Moore

6. Talicada nyseus Guerin Meneville (Photo 6a, b)

Polyommatus nyseus Guérin-Méneville (1843), Deless Sour. Inde: 78.t.22.f.i (Polyommatus)

Material examined: $(6 \hat{\jmath} 4$ 우우). India: Punjab: PAU, 04.xii.2009, Katewa, A. Seni and P.C. Pathania $(4 \overbrace{}^{\lambda} 2$ ㅇ),
PAU 24.viii.2012, Sunita, Kritika and P.C. Pathania (2^ 2ㅇ).

Distribution: It found in Central, Western and Southern India, Assam, Ceylon and Burma (Bingham, 1907).

Host plant: Crassulaceae (Saji et al., 2017).

Subfamily LYCAENINAE

VII. Genus Rapala Moore

7. Rapala iarbus Moore (Photo 7a, b)

Rapala jarbas Fabricius (1787), Mant. Ins. 2:68.

Material examined: (1 $\overbrace{}^{\Uparrow}$. India: Punjab: PAU, 08.v.2009,

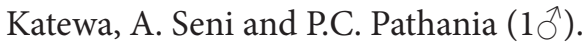

Distribution: South-east Asia from India to the Fiji, including the Philippines, and also the tropical coast of Queensland in Australia(Bingham, 1907).

Host plant: Connaraceae and Sapindaceae (Saji et al., 2017).

Family NYMPHALIDAE

Subfamily HELICONIINAE Rafinesque, 1815

VIII. Genus: Phalanta Doubleday

8. Phalanta phalanta (Horsfield) (Photo 8a,b)

Papilio phalantha Horsfield, 1829, Cat. Lep.E.Ind.Comp pl. 7 (Papilio).

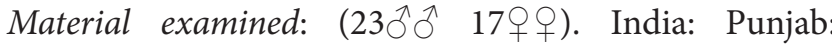
PAU, 11.viii.2011, Birpal, Amit and P.C. Pathania

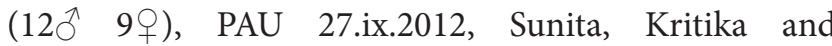
P.C. Pathania $(7 \hat{\jmath} 7$ ㅇ), Forest field, 14.viii.2015, Sachin and P.C. Pathania $(2 \hat{\jmath} 1$ 1 $)$, Floriculture garden, 14.viii.2015, Sachin and P.C. Pathania (1ठ),

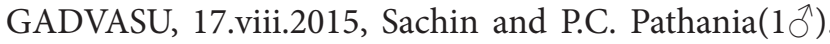
Distribution: It occurs nearly throughout Continental India, Ceylon, Assam, Burma, Tenasserim; extending to China, Japan and the Malayan Subregion (Bingham, 1905).

Host plant: Flacourtia species (Bingham, 1905).

Subfamily NYMPHALINAE

VIX. Genus Vanessa Fabricius

9. Vanessa cardui (Linnaeus) (Photo 9a,b)

Papilio cardui Linnaeus, 1758, Syst. Nat. 475 (Papilio).

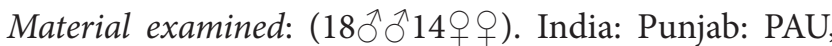

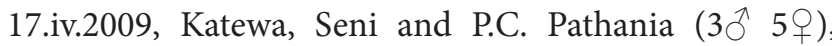


PAU, 8.xi.2009, Vijay and P.C. Pathania $(8 \overbrace{}^{\Uparrow} 4$ 우), PAU, 05.ix.2010, S. Kumar, Vijay and P.C. Pathania $(4 \hat{\jmath} 3$ + $)$, PAU, 13.iii.2011, Birpal, Amit and P.C. Pathania (3仓ึ 2ㅇ). Distribution: The painted Lady is distributed over the whole world, it occurs in and is recorded from all parts of India, Ceylon, Burma and Tenasserim, more plentifully in the hills (Bingham, 1907).

Host plant: Asteraceae, Fabaceae, Papaveraceae and Utricaceae (Kunte, 2000).

\section{Genus Hypolimnas Hübner}

10. Hypolimnas missipus (Linnaeus) (Photo 10a,b)

Papilio misippus Linnaeus, 1764, Verz. Bek. Schmett: 45.

Material examined: $(5 \hat{\jmath} \widehat{\jmath} 7 q$ q $)$. India: Punjab: PAU, 25.viii.2010, Vijay and P.C. Pathania $\left(1 \hat{O}^{\lambda} 3\right.$ \% $)$, PAU

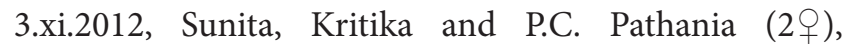
PAU, 14.viii.2015, Sachin and P.C. Pathania $\left(1 \hat{O}^{\lambda} 1\right.$ \% $)$, GADVASU, 17.viii.2015, Sachin and P.C. Pathania (2ત),

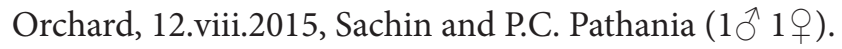
Distribution: It is found in the Himalayas up to 6000 feet; extending to the Malayan Subregion and China (Bingham, 1905).

Host plant: Portulaco oleracea (Bingham, 1905).

\section{Hypolimnas bolina (Linnaeus) (Photo 11a,b)}

Papilio bolina Linnaeus, 1758, Syst. Nat. 479.

Material examined: ( $6 \overbrace{}^{\widehat{\jmath}} 8$ 우). India: Punjab: PAU, 25.viii.2010, Vijay and P.C. Pathania $\left(2 \diamond^{\lambda}\right.$ 우), PAU 3.xi.2012, Sunita, Kritika and P.C. Pathania (3q), PAU, 14.viii.2015, Sachin and P.C. Pathania $\left(1 \delta^{\lambda} 1\right.$ \% $)$, GADVASU, 17.viii.2015, Sachin and P.C. Pathania $\left(2{ }^{\top}\right)$, Orchard, 12.viii.2015, Sachin and P.C. Pathania (1仓수).

Distribution: It is found in the Himalayas up to 6000 feet; extending to the Malayan Subregion and China (Bingham, 1905).

Host plant: Portulaco oleracea (Bingham, 1905).

\section{Genus Junonia Hubner}

\section{Junonia almana Linnaeus (Photo 12a,b)}

Papilio almana Linnaeus, 1758, Syst. Nat. 472.

Material examined: ( $8 \hat{\widehat{o}} \widehat{0}$ 5우). India: Punjab: PAU 8.viii.2012, Sunita, Kritika and P.C. Pathania $(2 \widehat{\jmath} 2$ \&),
PAU 30.ix.2012, Sunita, Kritika and P.C. Pathania $\left(2{ }^{\Uparrow}\right.$ 2 9$),$ PAU, 14.viii.2013, Avi Kumar and P.C. Pathania (4ð), Orchard, 12.viii.2015, Sachin and P.C. Pathania (19).

Distribution: Throughout our limits; abundant, in some districts found also in the Malayan Sub region, and in China and Japan (Bingham, 1905).

Host plant: Mimulis gracilis, Rice crop (Bingham, 1905).

\section{Junonia atlites (Linnaeus) (Photo 13a,b)}

Papilio atlites Linnaeus, 1763, Amoen Acad. 6: 407, n.72.

Material examined: $\left(1 \hat{O}^{\lambda}\right.$ 1 $)$. India: Punjab: PAU, 11.viii.2011, Birpal, Amit and P.C. Pathania (1ठ1ㅇ).

Distribution: It is found in Terai, at the foot of the Himalayas from Kumaun Sikkim; Eastern Bengal, Central Provinces, Kanara, Ceylon, Burma, extending to the Malaya sub region (Bingham, 1907).

Host plant: Acanthaceae (Saji et al., 2017).

\section{Junonia lemonias (Linnaeus) (Photo 14a,b)}

Papilio lemonias Linnaeus 1758, Syst. Nat: 473.

Material examined: (1 9 ). India: Punjab: PAU, 26.x.2010, Vijay and P.C. Pathania (1).

Distribution: It occurs in North West Himalayas as far as Kumaun; Punjab, Bengal, Western and Southern India, Ceylon (Bingham, 1907).

Host plant: Acanthaceae and Cannabaceae (Saji et al., 2017).

\section{Junonia orithya Linnaeus (Photo 15a,b)}

Junonia orithya Linnaeus, 1764, Mus. Ulr: 278.

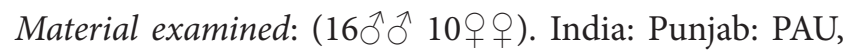

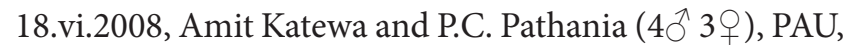
3.iii.2010, Vijay and P.C. Pathania $(6 \AA 2$ 우), PAU, 26.x.2010, Vijay and P.C. Pathania (5ð⿱ 2 + ), PAU 13.vii.2012, Sunita, Kritika and P.C. Pathania (3 + ), Floriculture garden,

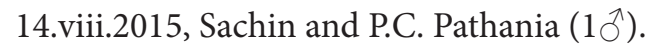

Distribution: It occursnearly throughout our limits, extending to China (Bingham, 1905).

Host plant: Amaranthus, Sweet Potato (Bingham, 1905).

16. Junonia hierta Fabricius (Photo 16a,b)

Junonia hierta Fabricius, 1798, Ent. Syst. Suppl.: 424. 
Material examined: (15大ㅅำ 9우). India: Punjab: PAU, 18.vi.2008, Amit Katewa and P.C. Pathania (4仓 3 \% ), PAU, 3.iii.2010, Vijay and P.C. Pathania (6 2 2 ) $)$, PAU, 26.x.2010, Vijay and P.C. Pathania (5 1 1 $)$, PAU 13.vii.2012, Sunita, Kritika and P.C. Pathania (3ㅇ), Floriculture garden,

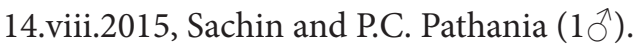

Distribution:It occursnearly throughout our limits, extending to China (Bingham, 1905).

Host plant: Amaranthus, Sweet Potato (Bingham, 1905).

Subfamily DANAINAE

XII. Genus Danaus Linnaeus

17. Danaus chrysippus (Linnaeus) (Photo 17a,b)

Papilio chrysippus Linnaeus, 1758, Syst. Nat. (ed.x): 471, n.81.

Material examined: (49ㅅㅅ 39우). India: Punjab: PAU, 14.iv.2009, Amit Katewa and P.C. Pathania (15ð 12), PAU, 8.ii.2010, Vijay and P.C. Pathania (19ð 15ㅇ), PAU,

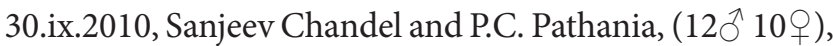
PAU, 14.viii.2015, Sachin and P.C. Pathania $\left(\begin{array}{ll}1 \hat{\alpha} & 1\end{array}\right)$, GADVASU, 17.viii.2015, Sachin and P.C. Pathania (10),

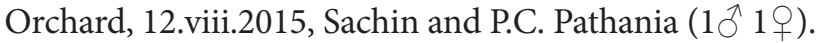

Distribution: Found in Southern Europe, Syria, over a great part of the Ethiopian Region, through Arabia, Persia, and Afghanistan. Eastwards it extends to China and through the Malayan Subregion to Sulu and the Celebes (Bingham, 1905).

Host plant: Apocynaceae (Saji et al., 2017).

\section{Danaus genutia (Cramer) (Photo 18a,b)}

Papilio genutia Cramer, 1779, Pap. Exot. 3: 23, t.206.

Material examined: (46کึ 35 우). India: Punjab: PAU, 14.iv.2009, Amit Katewa and P.C. Pathania (12犬 10 $)$, PAU, 8.ii.2010, Vijay and P.C. Pathania (21 $\widehat{\partial} 20$ 우), PAU, 30.ix.2010, Sanjeev Chandel and P.C. Pathania, $\left(6{ }^{\lambda} 3\right.$ ) PAU, 14.viii.2015, Sachin and P.C. Pathania $\left(4{ }^{\lambda} 1 q\right)$, GADVASU, 17.viii.2015, Sachin and P.C. Pathania (2ð), Orchard, 12.viii.2015, Sachin and P.C. Pathania (1ð1). Distribution: British India (Bingham 1905).

Host plant: Apocynaceae (Saji et al., 2017).

XIII. Genus Euploea Fabricius

19. Euploea core (Cramer) (Photo 19a,b)

Papilio core Cramer, 1780, Pap. Exot. 3: 133, t. 267.

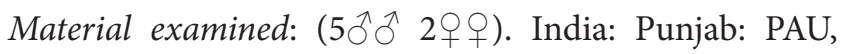

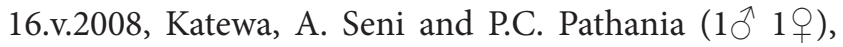
PAU, 15.ix.2009, Vijay and P. C. Pathania (2^ 1ㅇ), PAU 09.vii.2012, Sunita, Kritika and P.C. Pathania (2ત⿱) .

Distribution: Throughout continental India (Bingham, 1907).

Host plant: Apocynaceae, Moraceae and Sapotaceae (Saji et al., 2017).

\section{Genus Tirumala Moore}

20. Tirumala limniace Cramer (Photo 20a,b)

Papilio limniace Cramer, (1775), Pap. Exot. 1: 92, t. 59.

Material examined: $(1 \circlearrowleft)$. India: Punjab: Orchard, 12.viii.2015, Sachin and P.C. Pathania $\left(1{ }^{\jmath}\right)$.

Distribution: China, India, Sri Lanka, Pakistan, Bangladesh, Myanmar, and Thailand (Ambrose and Raj, 2005).

Host plant: Poaceae (Saji et al., 2017).

Subfamily SATYRINAE

XV. Genus Melanitis Fabricius

21. Melanitis leda Cramer (Photo 21a,b)

Melanitis lela Moore, 1758, Syst. Nat. (ed. 10): 474.

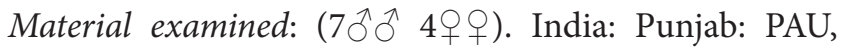
12.v.2008, Katewa, A. Seni and P.C. Pathania ( $1 \hat{O}^{\lambda} 1$ \%), PAU, 23.viii.2009, S. Chandel and P.C. Pathania $(2 \lesssim 1$ )

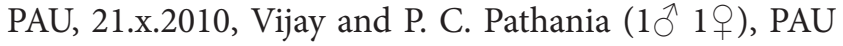
16.viii.2012, Sunita, Kritika and P.C. Pathania $\left(1 \delta^{\Uparrow} 1\right.$ ) $)$,

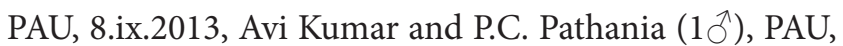
4.vii.2015, Sachin and P.C. Pathania (1ठ).

Distribution: It ranges from Indo-Malayan Region down to Australia, Burma, Ceylon (Bingham, 1907).

Host plant: Apluda spp., Cyrtococcum spp., Eleusine spp., Oplismenus composites, Oryza sativa, Panicum spp., Sorghum spp., Zea spp., (Kunte, 2000).

\section{Family PAPILIONIDAE}

Subfamily PAPILIONINAE

XVI. Genus Papilio Linnaeus

\section{Papilio demoleus Linnaeus (Photo 22a,b)}

Papilio demoleus, Linnaeus, 1758, Syst. Nat. (ed.10): 464. N. 35 .

Material examined: (29ðึ $\hat{\partial} 16$ 우). India: Punjab: PAU, 26.iii.2010, Vijay and P.C. Pathania $(8 \hat{0} 6$ 6 $)$, PAU, 
25.viii.2010, Vijay and P.C. Pathania (5犬̂ 2ᄋ), PAU 13.vii.2012, Sunita, Kritika and P.C. Pathania $(8 \hat{\jmath} 4$ 우), PAU, 5.xii.2012, Sunita, Kritika and P.C. Pathania $\left(3{ }^{\lambda}\right.$ 1ㅇ), PAU, 11.viii.2015, Sachin and P.C. Pathania $(2 \widehat{\jmath}$ 19), GADVASU, 17.viii.2015, Sachin and P.C. Pathania (3ð 1ㅇ), CIPHET, 11.viii.2015, Sachin and P.C. Pathania (1우).

Distribution: Kashmir to Ceylon; Assam to upper Burma, up to a moderate elevation; extending to Persia and eastwards to China and Formosa (Talbot, 1939).

Host plant: Aegle marmelos, Chloroxylon swietenia, Citrus aurantifolia, Citrus grandis, Citrus limon, Citrus sinensis, Glycosmis arborea, Murreaya koenigii, Ruta graveolens (Kunte, 2000).

\section{Papilio polytes romulus Cramer (Photo $23 \mathrm{a}, \mathrm{b} \& 24 \mathrm{a}, \mathrm{b}$ )}

Papilio polytes romulus Cramer, 1758, Pap. Exot. 1: 67, t.43.

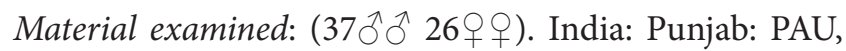
17.iv.2009, Amit Katewa and P.C. Pathania $(3 \hat{\jmath} 2$ 우), PAU, 6.v.2009, Amit Katewa and P.C. Pathania (7ð 4우), PAU, 1.ix.2010, Vijay and P.C. Pathania (50 2 $)$ ), PAU, 11.viii.2011, Birpal, Amit and P.C. Pathania ( $1 \delta^{\Uparrow} 2$ \% ), PAU

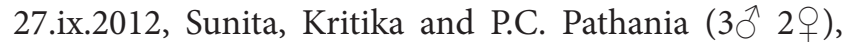
PAU, 20.xi,2012, Sunita, Kritika and P.C. Pathania (4ત 3), PAU 30.xi,2012, Sunita, Kritika and P.C. Pathania (2 4 4 ), PAU, 13.viii.2013, Avi Kumar and P.C. Pathania (5 5 +), PAU, 11.viii.2015, Sachin and P.C. Pathania $\left(4{ }^{\Uparrow}\right)$. GADVASU, 17.viii.2015, Sachin and P.C. Pathania $\left(1 \delta^{\Uparrow} 1\right.$ ) $)$, Floriculture garden, 14.viii.2015, Sachin and P.C. Pathania (1ठ 1ㅇ), CIPHET, 11.viii.2015, Sachin and P.C. Pathania $\left(1{ }^{\Uparrow}\right)$.

Distribution: Throughout Asia, Pakistan and southern Asia, including India and all regions east of it, Malaysia and Indonesia, and on the coast of southern China, the Philippine islands, and the southwestern islands of Japan (Suwarno, 2010).

Host plant: Atalantia racemosa, Aegle marmelos, Citrus aurantifolia, Citrus grandis, Citrus limon, Citrus medica, Citrus sinensis, Glycosmis arborea, Murraya koenigii, Murraya paniculata, Tripahsia sp., Zanthoxylum rhetsa (Kunte, 2000).

Distribution: Nicobar Islands (Talbot, 1939).

Host plant: Citrus, Murraya, Triphasia, Xanthoxylon (Talbot, 1939)
XVII. Genus Graphium Scopoli

24. Graphium doson (Felder) (Photo 25a, b)

Papilio doson Felder, 1864, Verh. zool. bot. Ges. Wien.: 305.

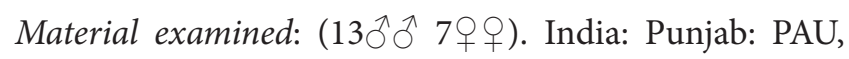
26.ix.2011, Birpal, Amit and P.C. Pathania $\left(4{ }^{\lambda} 2\right.$ 2 $)$, PAU 27.ix.2012, Sunita, Kritika and P.C. Pathania (30 2ᄋ), PAU, 1.xi.2013, Avi Kumar and P.C. Pathania (4仓 2 ㅇ), Forest field, 14.viii.2015, Sachin and P.C. Pathania (2へ 1ㅇ), CIPHET, 11.viii.2015, Sachin and P.C. Pathania (10̂).

Distribution: South Japan to South China and Ceylon, southwards and eastwards to the Sunda Islands. Several subspecies are known, of which three occur in the Indian area (Talbot, 1939).

Host plant: Annona lawii, Cinnamomum macrocarpum, Magnolia grandiflora, Michelia champaca, Miliusa tomentosum, Polyalthia longifolia, Annonaceae, Lauraceae, Magnoliaceae (Kunte, 2000).

Family PIERIDAE

Subfamily PIERINAE

XVIII. Genus Belonois Hubner

25. Belonois aurota Fabricius (Photo 26a, b)

Belonois aurota Fabricius, 1793, Ent. Syst. 3, 1: 197.

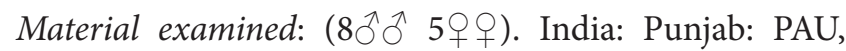
6.v.2009, Amit Katewa and P.C. Pathania (3 $\hat{\jmath}_{1} 1$ 우), PAU, 8.x.2010, Vijay and P.C. Pathania (2ð 2 + ), PAU 3.xi.2012,

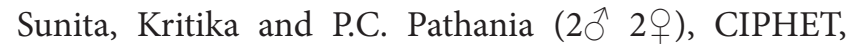
11.viii.2015, Sachin and P.C. Pathania $\left(1{ }^{\Uparrow}\right)$.

Distribution: It found in all India except Assam and Burma. A straggler is recorded from Great Nicobar. The subspecies also extends to Palestine and Africa (Talbot, 1939).

Host Plant: Cadaba fruticosa, Capparis decidua, Capparis pyrifolia, Capparis rheedii, Capparis sepiaria, Capparis spinosa, Capparis zeylanica, Maerua oblongifolia (Kunte, 2000).

XIX. Genus Cepora Billberg

26. Cepora nerissa Fabricius (Photo 27a, b)

Cepora Nerissa Fabricius, 1775. Syst. Ent.: 441.

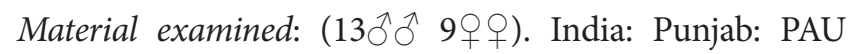
5.xii.2012, Sunita, Kritika and P.C. Pathania $(2 \widehat{\jmath} 2$ \% ), PAU, 
2.xi.2013, Avi Kumar and P.C. Pathania (4ð 3 १), PAU, 14.viii.2015, Sachin and P.C. Pathania $(5 \hat{\jmath} 3$ \%), GADVASU, 17.viii.2015, Sachin and Pathania $(2 \AA 1 \%)$.

Distribution: It found in Ceylon, India, Burma, and Andaman Islands, north to Formosa, south to Sumbawa (Bingham, 1907).

Host plant: Cadaba fruticosa, Capparis decidua, Capparis rheedii, Capparis sepiaria, Capparis zeylanica, Maerua oblongifolia (Kunte, 2000).

XX. Genus Ixias Hubner

27. Ixias mariane Cramer (Photo 28a, b)

Ixias marianae Cramer, 1779. Exot. III. : 41.

Material examined: ( $5 \hat{\jmath} \widehat{\jmath}+q$ ). India: Punjab: PAU 13.xii.2012, Sunita, Kritika and P.C. Pathania $(2 \hat{\bigcirc} 2 \bigcirc)$, PAU 17.xii.2012, Sunita, Kritika and P.C. Pathania (2ळ 1), PAU, 18.ix.2013, Avi Kumar and P.C. Pathania $\left(1 \sigma^{\Uparrow}\right)$.

Distribution: It occurs in North West Himalayas as far as Kumaun; Punjab, Bengal, Western and Southern India, Ceylon(Bingham, 1907).

Host plant: Capparis deciduas, Capparis divaricata, Capparis grandis, Capparis sepiaria (Kunte, 2000).

28. Ixias pyrene Linneaus (Photo 29a, b)

Ixias pyrene Linnaeus, 1764. Mus. Ulr. : 241.

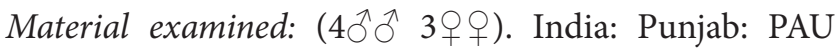
5.xii.2012, Sunita, Kritika and P.C. Pathania $(2 \hat{\jmath} 2$ ㅇ), PAU, 2.xi.2013, Avi Kumar and P.C. Pathania (2 $\bigcirc_{1}$ ㅇ).

Distribution: It is the commonest and most widespread member of the genus. It is distributed in India, Pakistan to Taiwan, Malaysia, Borneo and the Philippines (Bingham, 1907).

Host plant: Capparis sepiaria (Kunte, 2000).

XXI. Genus Pieris Schrank

29. Pieris brassicae Linnaeus (Photo 30a, b)

Papilio brassicae Linnaeus, 1758. Syst. Nat. ed. X: 467.

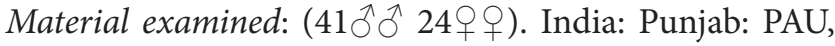

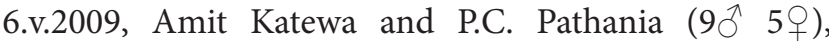
PAU, 6.iv.2010, Vijay and P.C. Pathania (14ð 6ㅇ), PAU 4.viii.2012, Sunita, Kritika and P.C. Pathania (10 8 ㅇ) PAU, 16.ix.2013, Avi Kumar and P.C. Pathania ( $8 \hat{\jmath} 5$ 우).

Distribution: Baluchistan and Chitral (Pakistan) eastwards to Assam, very common in Himalayas and plains adjoining Himalayas, ascending to about 12,000 feet in Himalayas (Kumar, 2008).

Host plant: Brassicaceae (Kunte and Soman, 2017).

Subfamily COLIADINAE XXII. Genus Catopsila Hubner

30. Catopsilia Pomona Fabricius (Photo 31a, b)

Catopsilia pomona Fabricius, 1775. Syst. Ent. : 479.

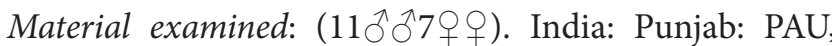
8.viii.2009, Katewa, Seni and P.C. Pathania ( $3 \overbrace{}^{\lambda} 2$ \% ), PAU, 12.x.2009, S. Chandel and P.C. Pathania ( $2 \hat{\jmath} 1$ \% $)$, PAU, 6.iv.2010, Vijay and S. Kumar (2ð 2 + ), PAU, 11.viii.2011, Birpal, Amit and P.C. Pathania (1ठำ), PAU 4.vii.2012, Sunita, Kritika and P.C. Pathania (2 $\overbrace{}^{\Uparrow}$ ), PAU, 16.x.2013, Avi Kumar and P.C. Pathania (1 $\overbrace{}^{\Uparrow})$.

Distribution: It found in Ceylon, India, Burma, Andman Islands and Nicobar Islands; South China to Soloman Islands and Austerlia. (Bingham, 1907).

Host plant: Cassia fistula (Talbot, 1939)

31. Catopsilia pyranthe Linneaus (Photo 32a, b)

Papilio pyranthe Linnaeus, 1758. Syst. Nat. I.1: 469.

Material examined: (16万人 9우). India: Punjab: PAU, 28.vii.2010, Vijay and P.C. Pathania $(3 \hat{\jmath} 3$ + $)$, PAU, 12.ix,2012, Sunita, Kritika and P.C. Pathania $(2 \hat{\jmath} 2$ q $)$, PAU, 30.xi,2012, Sunita, Kritika and P.C. Pathania $(3 ð$ 1 )), PAU, 11.viii.2015, Sachin and P.C. Pathania $(2 ð$ 19), GADVASU, 17.viii.2015, Sachin and P.C. Pathania $(10$ 2 2 \%), Floriculture garden, 14.viii.2015, Sachin and P.C. Pathania $\left(3{ }^{\lambda}\right)$, CIPHET, 11.viii.2015, Sachin and P.C. Pathania (2ત⿱) .

Distribution: It found throughout India; Assam; Burma; Tenasserim; not ascending the Himalayas to above 7000 $\mathrm{ft}$. It extends to China on the east and as far as Australia southwards (Bingham, 1907).

Host plant: Cassia auriculata, Cassia fistula, Cassia occidentalis, Cassia tora, Gnidia glauca, Sesbania bispinosa (Kunte, 2000). 
XXIII. Genus: Colias Fabricius

32. Colias electo fieldi Ménétriés (Photo 33a, b)

Colias fieldi fieldi Ménétriés, 1855. Cat. Mus. Petr. Lep. I: 79. Material examined: (9仓̋ 4 우). India: PAU, 20.viii.2010, Vijay and P. C. Pathania (5 2 ) $)$, PAU 04.xii.2012, Sunita,

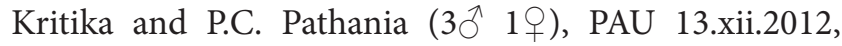

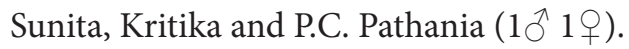

Distribution: Baluchistan to North Punjab, Sikkim, northern Burma, more common in the Western Himalaya. (Bingham, 1907).

Host plant: Caterpillars feed on Fabaceae, for example vetches (Vicia). While most are thus beneficial by keeping weeds at bay, some occasionally become nuisance pests on crops like alfalfa (Kunte, 2000).

\section{Genus Eurema Hubner}

33. Eurema hecabe Linnaeus (Photo 34a,b)

Papilio hecabe Linnaeus, 1758. Syst. Nat. ed. X: 470.

Material examined: (17ठぇ 14 우). India: Punjab: PAU, 8.viii.2009, Katewa, Seni and P.C. Pathania (3ð̂ 2 + $)$, PAU, 12.x.2009, S. Chandel and P.C. Pathania $\left(2 \bigcirc^{\Uparrow} 1\right.$ \%), PAU, 6.iv.2010, Vijay and S. Kumar (2ð 2 9 ), PAU, 11.viii.2011, Birpal, Amit and P.C. Pathania (1 $\delta_{1}$ 1 ), PAU 4.vii.2012, Sunita, Kritika and P.C. Pathania (2ð 1 $\overbrace{\text { ) }}$, PAU, 16.x.2013,

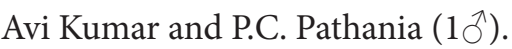

Distribution: British India (Bingham, 1905).

Host plant: The early stages of Common Grass Yellow are polyphagous with most of its host plants belonging to the Fabaceae family. The caterpillars feed on the young and tender leaves of the host plants. Eggs are laid on Abrus precatorius, Acacia spp., Aeschynomene spp., Albizzia spp. and numerous other Leguminosae, Euphorbiaceae and Cucurbitaceae species (Kunte, 2000).

\section{Acknowledgements}

The authors are very grateful to Head, Department of Entomology for providing lab facilities. Thanks are also due to Dr. V. V. Ramamurthy, Retd. Principal Scientist, NPC, Dr. Kailash Chandra, Director, ZSI, Kolkata and IARI, New Delhi for their help and provide necessary permission for consultation of museum collection.

\section{References}

Ambrose, D.P. and Raj, D.S. 2005. Butterflies of Kalakad-Mundanthurai tiger reserve, Tamil Nadu. Zoos' Print Journal, $20: 2100-07$. Anonymous. 2017. Neptis soma Moore, 1858-Creamy Sailer. Kunte, K., P. Roy, S. Kalesh and U. Kodandaramaiah (eds.). Butterflies of India, v. 2.24. Indian Foundation for Butterflies.

Bingham, C.T. 1905. The Fauna of British India. Butterflies vol. VI. Taylor and Francis Red lion court, fleet street, London. pp. 11-413. Bingham, C.T. 1907. The Fauna of British India. Butterflies vol. II. Taylor and Francis Red lion court, fleet street, London. pp. $219-222$.

Chandrasekharan, V.K. 2017. Pelopidas mathias Fabricius, 1798 - Small Branded Swift. Kunte, K., P. Roy, S. Kalesh and U. Kodandaramaiah (eds.). Butterflies of India, v. 2.24. Indian Foundation for Butterflies.

Common, I.F.B. 1970. Lepidoptera (Moths and butterflies), in the insect of Australia. 1-866, Melbourne University Press, Melbourne.

Daily, G.C. 1997. Introduction: What are ecosystem services? Pages 1-10 in G. Daily, editor. Nature's Services: Societal Dependence on Natural Ecosystems. Island Press, Washington, D.C.

Talbot, G. 1939. The fauna of British India. Butterfly vol. I Taylor and Francis Red lion court, fleet street, London. P. $184-414$.

Gaonkar, H. 1996. Butterflies of Western Ghats with notes on those of Sri Lanka. A report of Center of Ecological Sciences, Indian Institute of science, Bangalore, Zoological Museum, Copenhagen and Natural History Museum, London.

Ghazoul, J. 2002. Impact of logging on the richness and diversity of forest butterflies in a tropical dry forest in Thailand. Biodivers. Conserv. 11: 521-541.

Haribal, M. 1992.The Butterflies of Sikkim Himalaya and their Natural History. Published by Sikkim Nature Conservation Foundation (SNCF), Gangtok, Sikkim, 217pp.

Heppner, J. 1998. Classification of Lepidoptera. Part I Introduction. Holarctic Lepidoptera 5: 148.

Javed, I. 1978. Preliminary report of butterflies of district Rawalpindi and Islamabad. Biologia, 24(2): 238-247.

Khan, M.R., Nasim, M., Khan, M.R. and Rafi, M.A. 2004. Diversity of butterflies from district Muzaffarabad, Azad Kashmir. Pakistan Journal of Biological Sciences, 7(3): 324-327.

Kirby, W.F. 1872. On the geographical distribution of the diurnal Lepidoptera as compared with that of the birds. J. Linn. Soc. Lond., Zoo. 11:431-439.

Kumar, P. 2008. Handbook on Common Butterflies of Uttarakhand. Zool. Surv. India. 1-136.

Kunte, K. 2000. Butterflies of Peninsular India. Universities Press (Hyderabad) and Indian Academy of Sciences, Bangalore. 270pp. 
Kunte, K. 2006. Additions to the known larval host plants of Indian Butterflies. Journal of Bombay Natural History Society. 103(1): 119-122.

Kunte, K. and Soman, A. 2017. Pieris brassicae Linnaeus, 1758 - Large Cabbage White. Kunte, K., P. Roy, S. Kalesh and U. Kodandaramaiah (eds.). Butterflies of India, v. 2.24. Indian Foundation for Butterflies.

Landing, B.H. 1984. Factors in the distribution of butterfly color and behavior patterns-Selected aspects. Privately published, Los Angeles. 200 pp.

Mal, B., Memon, N., Shah, M.A. and Shah, N.A. 2013. Re description and New Record of Small Arab Group of Genus Colitis (Lepidoptera: Pieridae) from Jamshoro, Sindh, Pakistan. Sindh Univ. Res. Jour. (Sci. Ser.), 45(2): 357-364.

Rafi, M.A., Matin, M.A., Sheikh, M.K. and Ashfaque, M. 2000. Papilionid (swallowtails) butterflies of Pakistan. Gul Awan Printers, Islamabad, Pakistan, 2: 1-33.

Rose, H.S. and Walia, V.K. 2003. Inventory of the Butterflies diversity of Chandigarh. Bionotes, 5(3): 58-60.

Saji, K. and Manoj, P. 2017. Telicota bambusae Moore, 1878- Dark Palm-Dart. Kunte, K., P. Roy, S. Kalesh and U. Kodandaramaiah (eds.). Butterflies of India, v. 2.24. Indian Foundation for Butterflies

Saji, K.A., Soman and Karmakar, T. 2017. Melanitis leda Linnaeus, 1758 - Common Evening Brown. Kunte, K., P. Roy, S. Kalesh and U. Kodandaramaiah (eds.). Butterflies of India, v. 2.24. Indian Foundation for Butterflies.

Suwarno. 2010. Population dynamic of the swallowtail butterfly, Papilio polytes (Lepidoptera: Papilionidae) in dry and wet seasons. Biodiversitas, 11(1): 19-23.

Wilson, E. 1997. Introduction.In Reakakudla ML, Wilson DE, Wilson EO, editors. Biodiversity II. Washington DC. Henry Press., 1-3.

Steve, W. 2005. Field Guide to Butterflies of South Africa. Cape Town, South Africa: Struik. ISBN 978-1-86872-724-7.

Zimmerman, E.C. 1978. Microlepidoptera. Ins. Hawaii, Vol. 9. University Press of Hawaii, Honolulu, 18: 1-1903. 


\section{PLATE 1}

Family: Hesperiidae

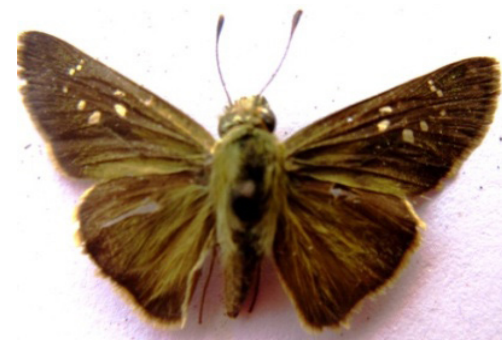

1a

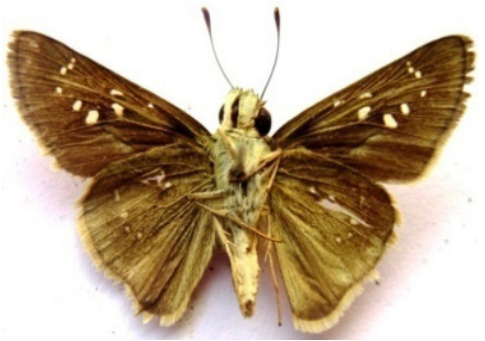

$1 b$

Figure 1. 1-Pelopidas mathias

Family: Lycaenidae

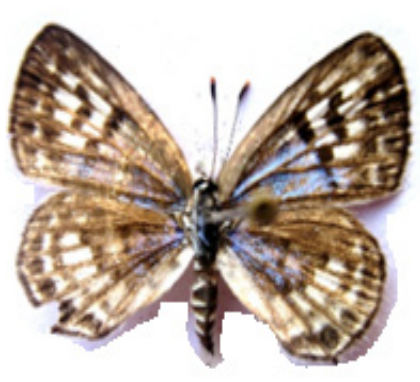

2a

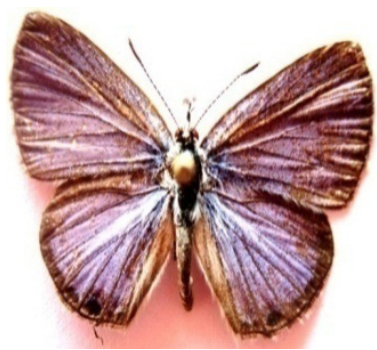

$4 a$

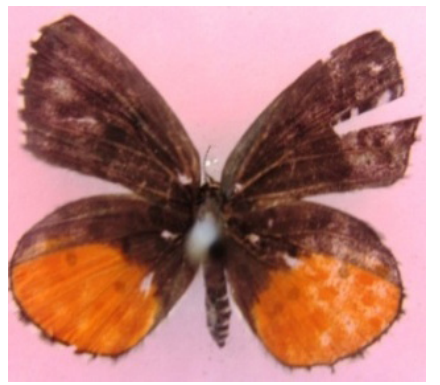

6a



2b

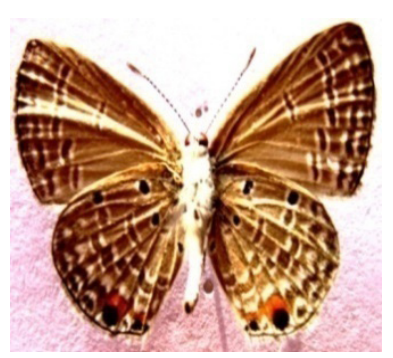

$4 b$

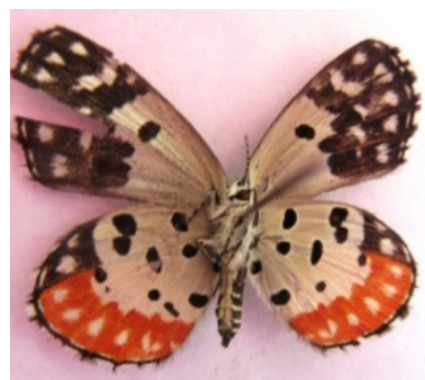

6b

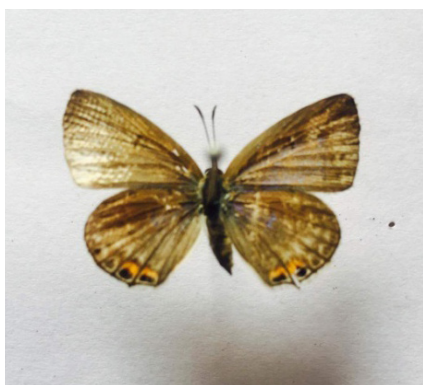

$3 \mathbf{a}$

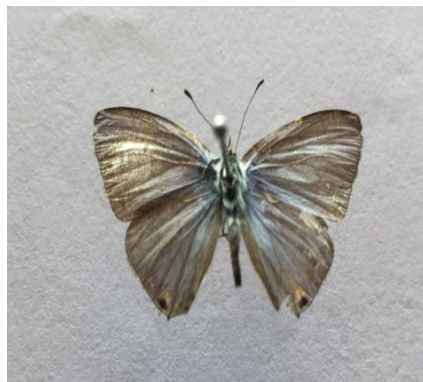

$5 a$

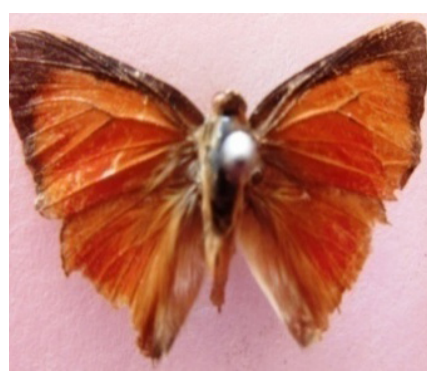

$7 \mathbf{a}$

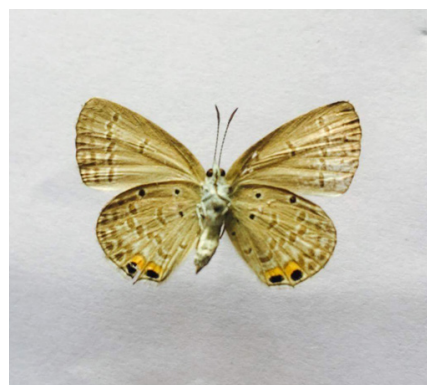

$3 b$

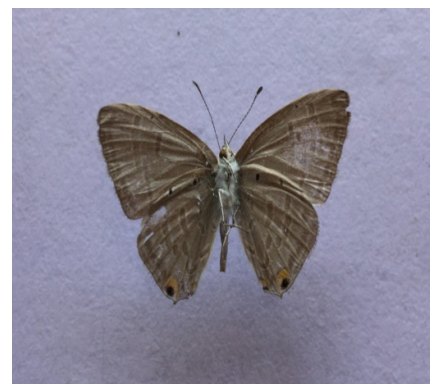

$5 b$

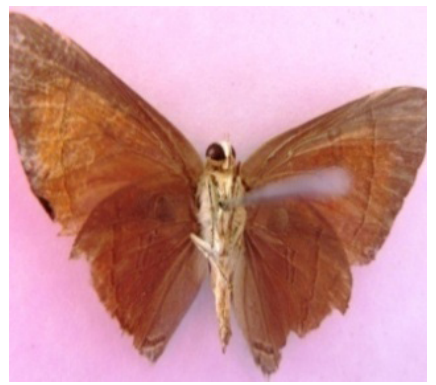

$7 \mathbf{b}$

Figure 2-8. 2-Tarucus callinara; 3-Euchrysops cnejus; 4-Chilades pandava; 5-Catochrysops strabo;6- Talicada nyseus; 7- Rapala airbus (a: Upper side, b: Lower side). 
Family: Nymphalidae



$8 \mathbf{a}$

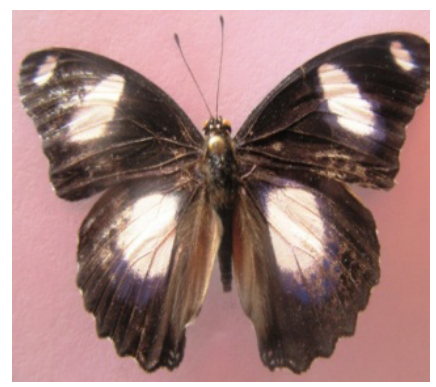

$10 a$

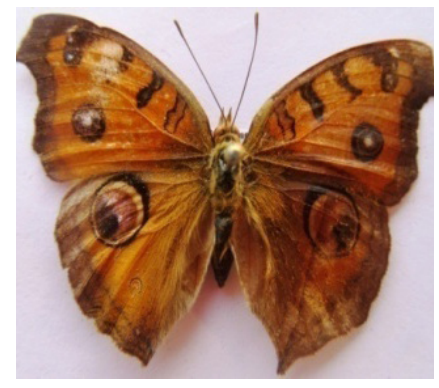

$12 \mathbf{a}$

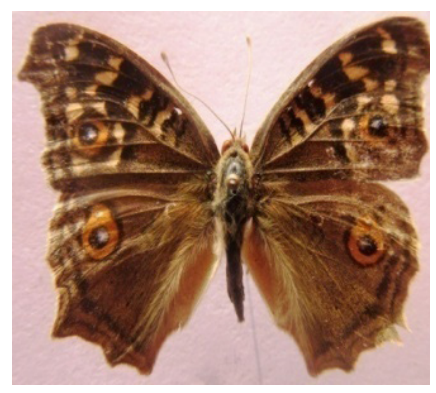

$14 a$

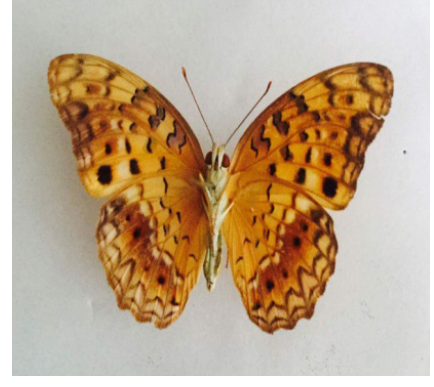

8b

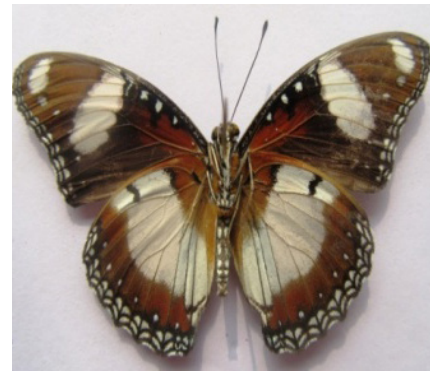

10b

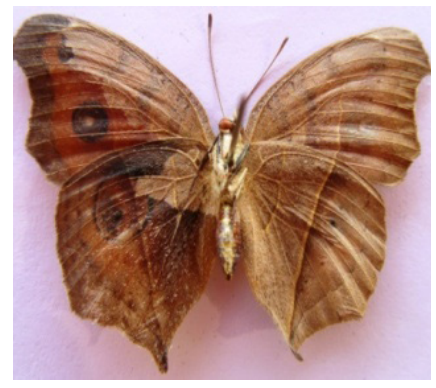

$12 b$

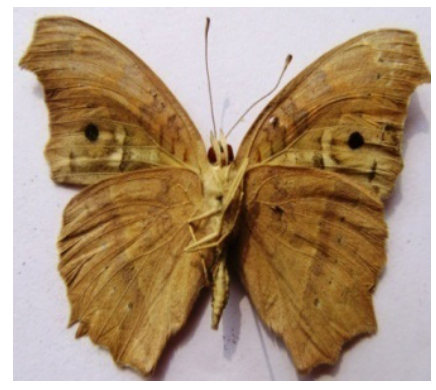

$14 b$

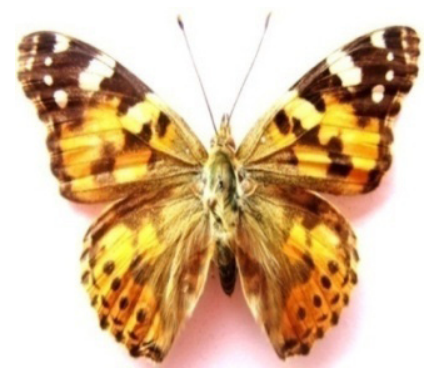

$9 a$

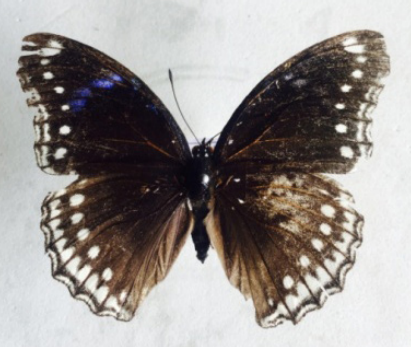

$11 a$

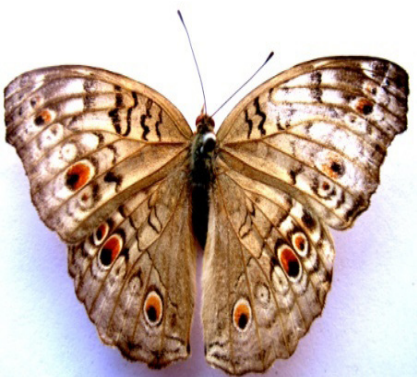

$13 a$

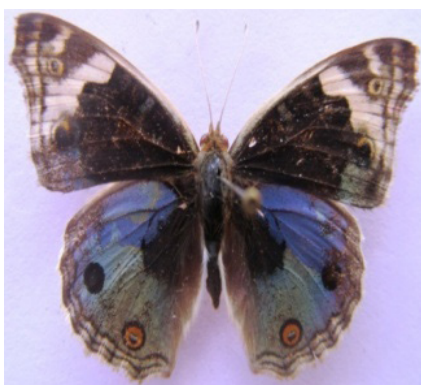

$15 a$

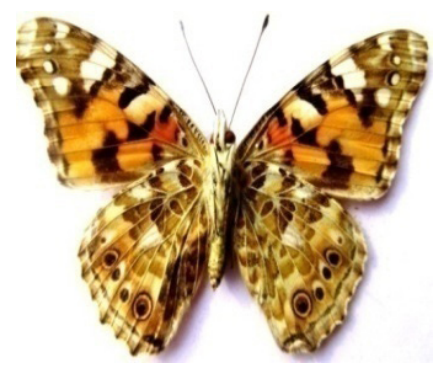

$9 b$

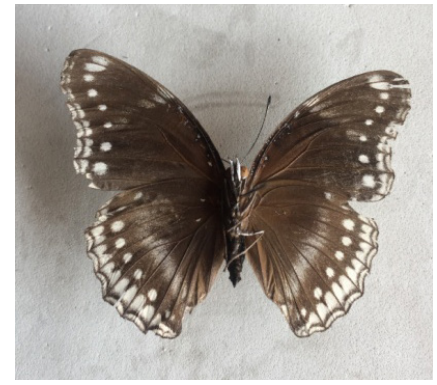

$11 b$

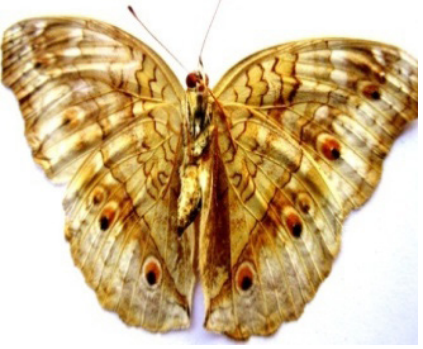

$13 b$

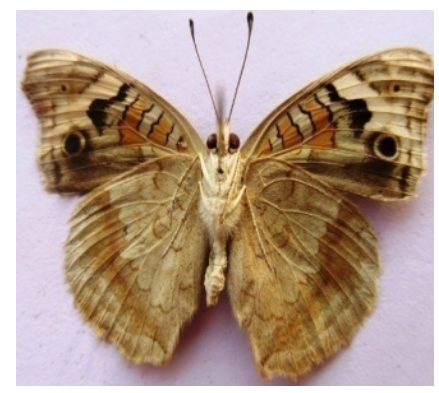

$15 b$ 


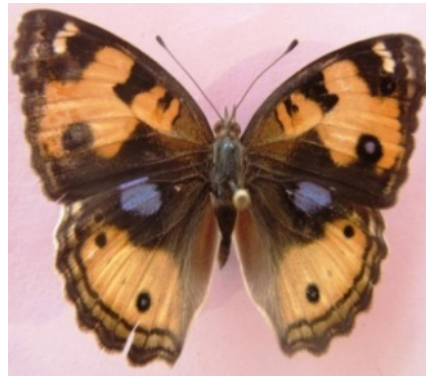

$16 a$

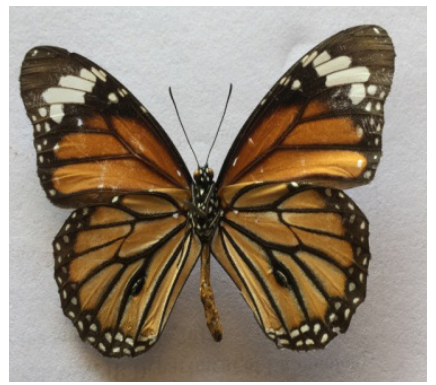

$18 \mathbf{a}$

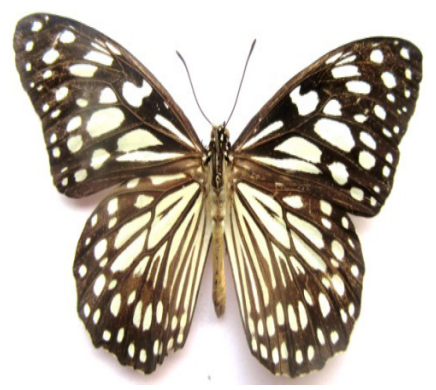

20a

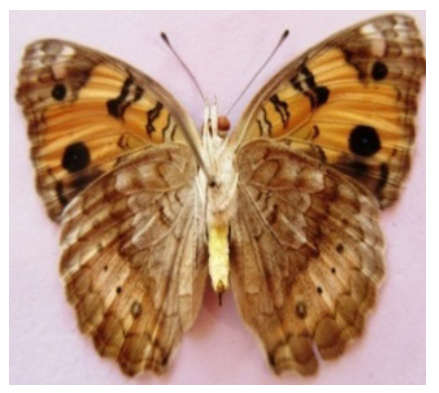

16b

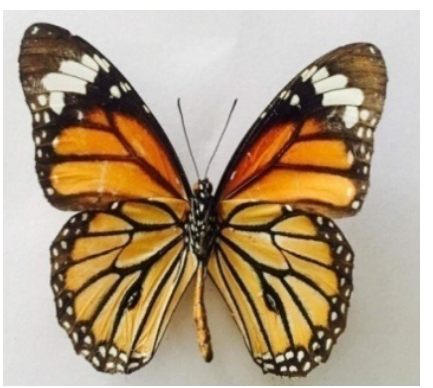

$18 b$

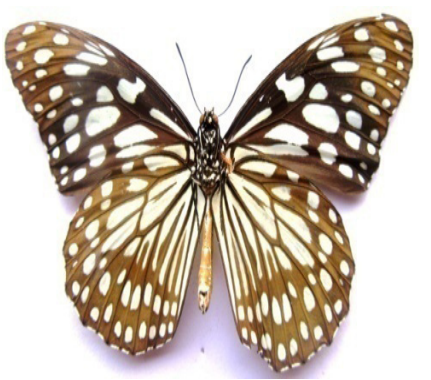

20b

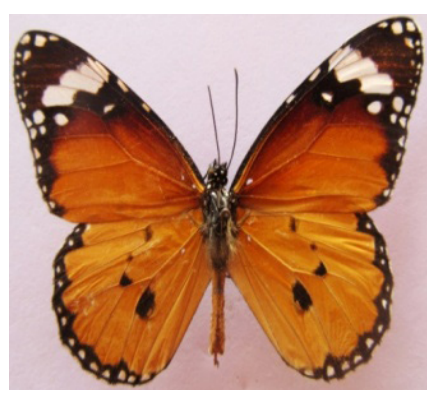

$17 \mathbf{a}$

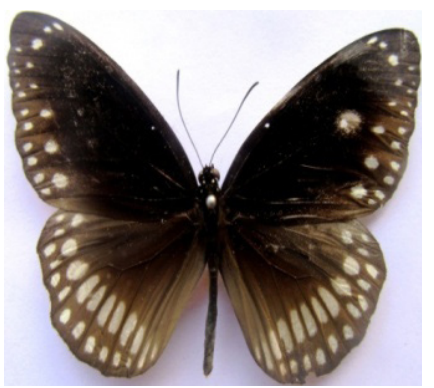

19a

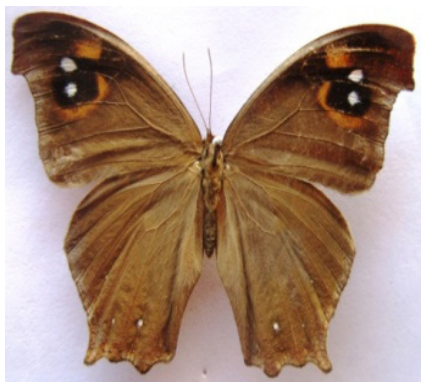

21a

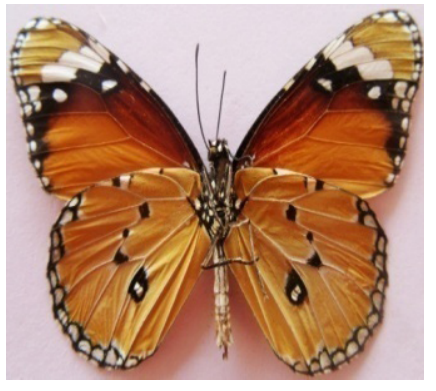

17b

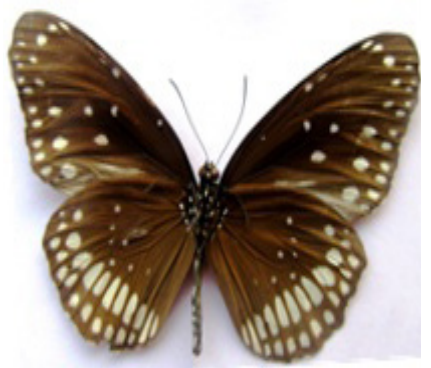

19b

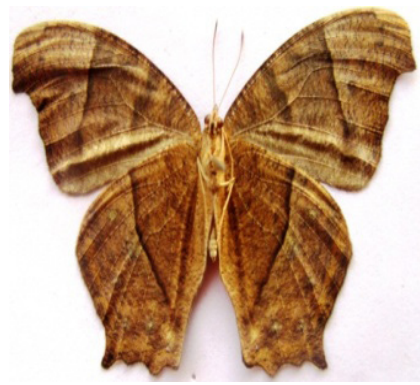

$21 b$

Figure 8-21. 8- Phalanta phalantha; 9- Vanessa cardui; 10- Hypolimnas missipus; 11-Hypolimnas bolina; 12-Junonia almana; 13- Junonia atlites; 14- Junonia lemonias; 15- Junonia orithya; 16- Junonia hierta 17- Danaus chrysippus; 18Danaus genutia; 19- Euploea core; 20-Tirumala limniace; 21- Melanitis leda. 
Family: Papilionidae

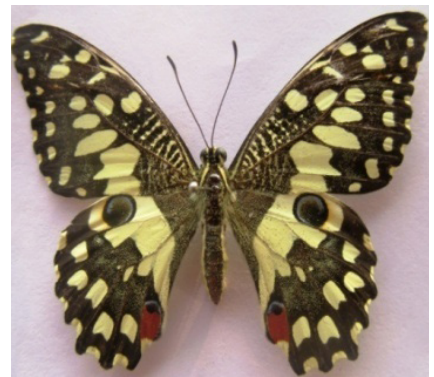

$22 \mathrm{a}$

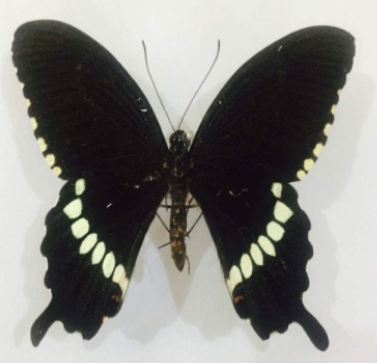

$24 a$

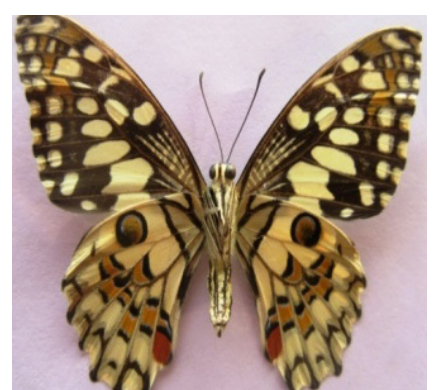

22b

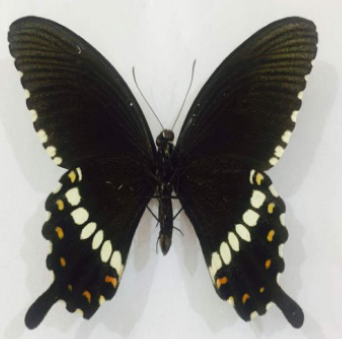

24b

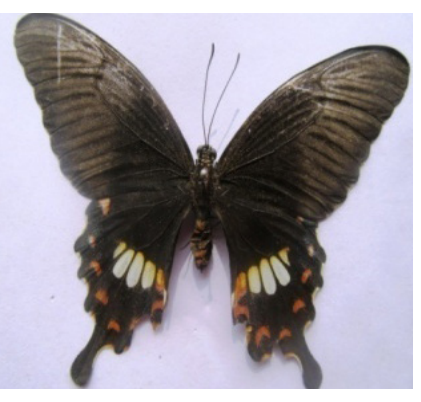

23a

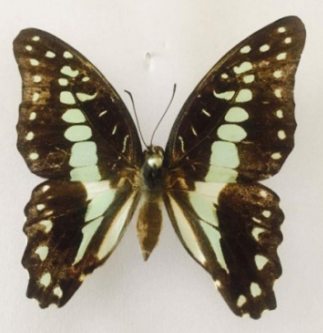

25a

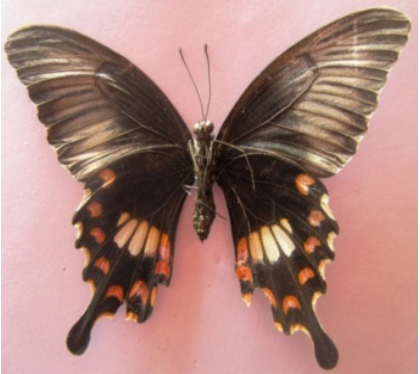

23b

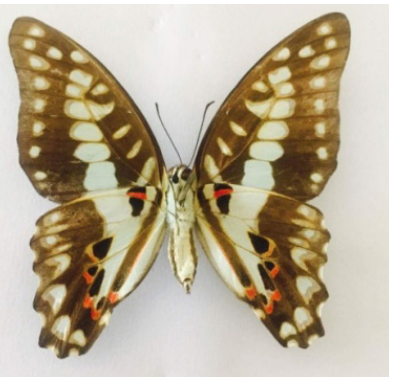

25b

Figure 22-25. 22- Papilio demoleus; 23-24 Papilio polytes romolus; 25- Graphium doson (a: Upper side, b: Lower side).

Family: Pieridae

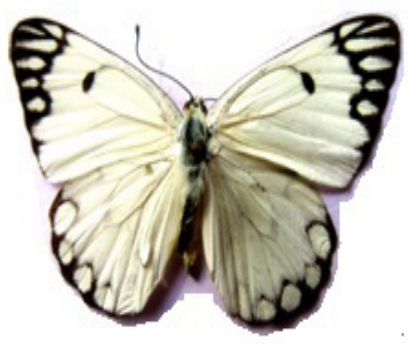

$26 a$

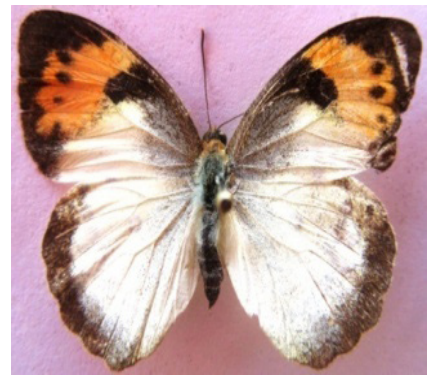

28a

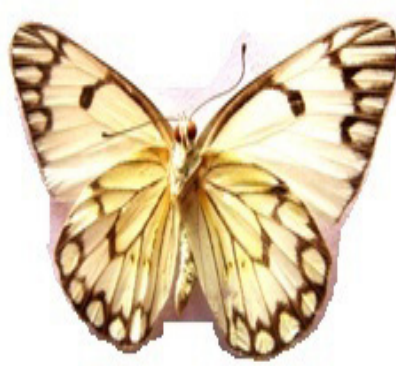

26b

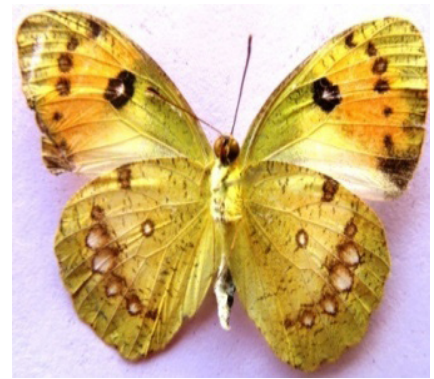

$28 b$

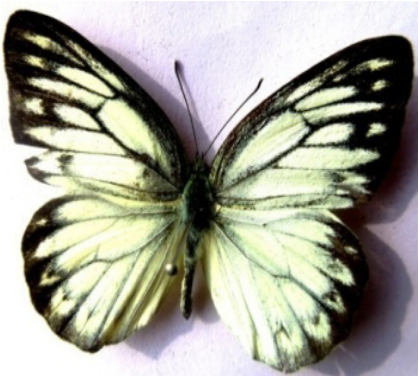

$27 \mathbf{a}$

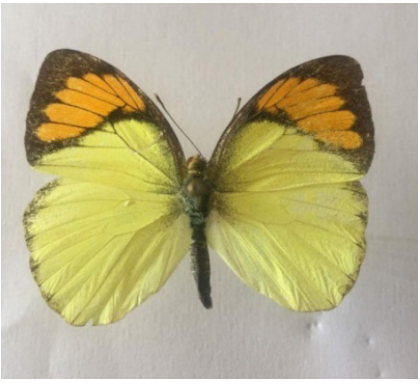

29a

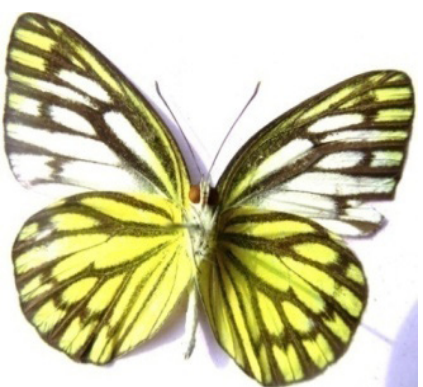

27b

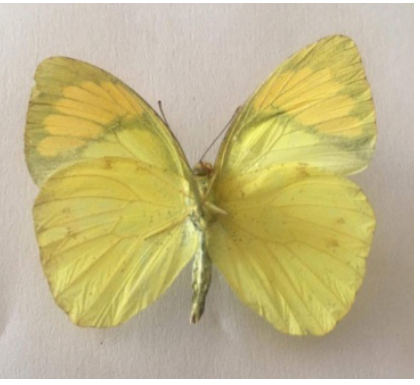

29b 


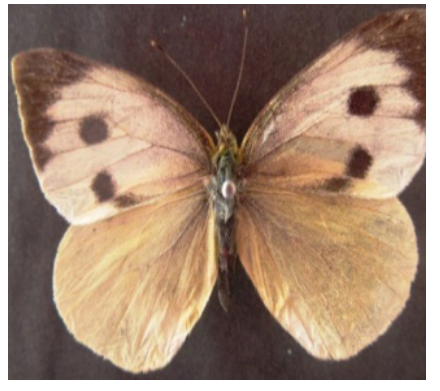

$30 a$

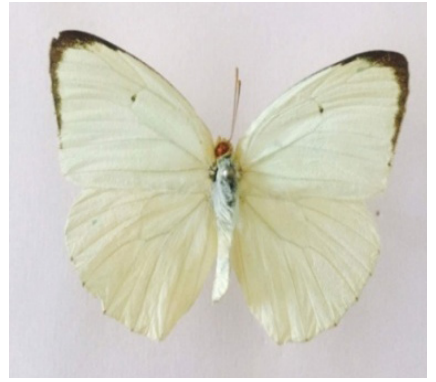

$32 \mathbf{a}$

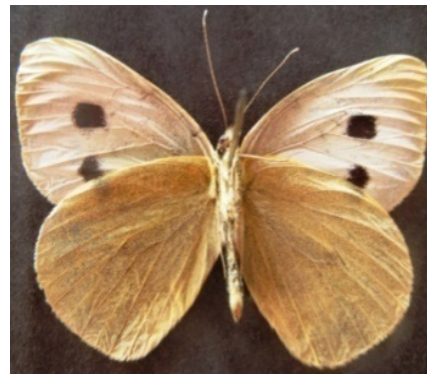

30b

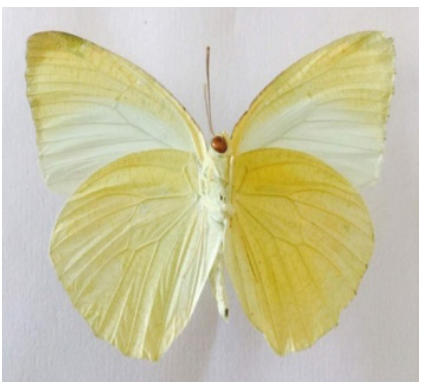

32b

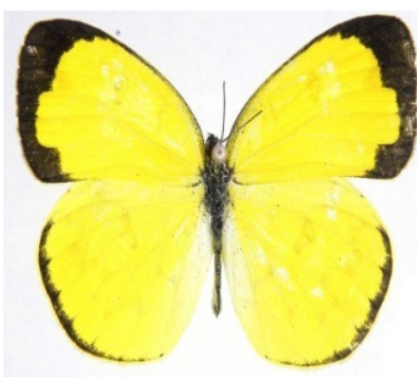

$34 a$

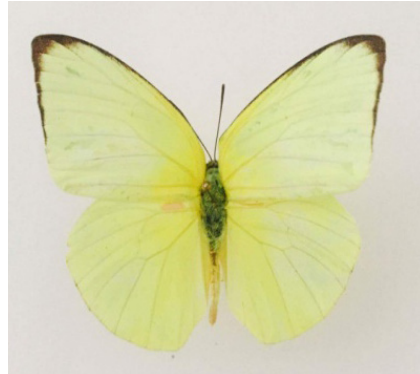

31a

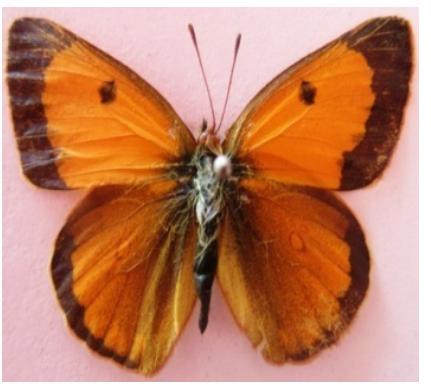

$33 a$

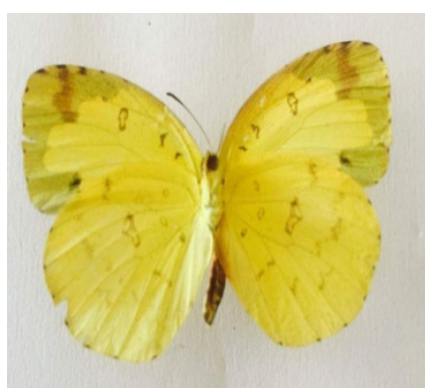

$34 \mathbf{b}$

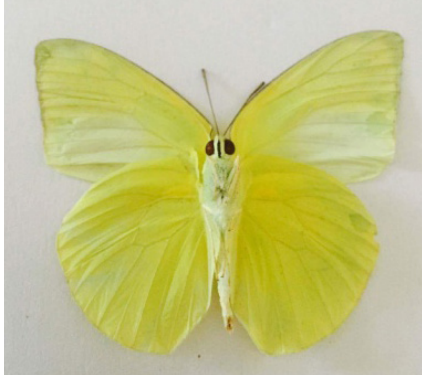

$31 b$

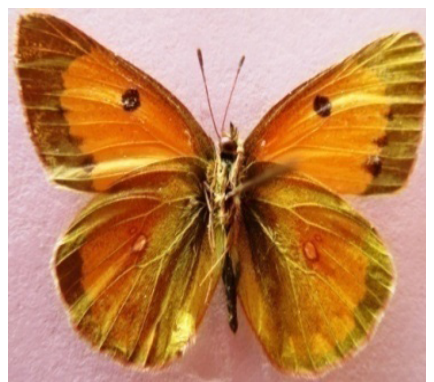

33b

Figure 26-34. 26-Belonois aurota; 27-Cepora nerissa; 28-Ixias marianne; 29- Ixias pyrene; 30-Pieris brassicae; 31-Catopsilia pomona; 32-Catopsilia pyranthe; 33-Colias fieldii 34-Eurema hecabe (a: Upper side, b: Lower side). 